\title{
DESIGN ANALYSIS OF IMPRESSED CURRENT CATHODIC PROTECTION (ICCP) SYSTEM FOR UNDERWATER STRUCTURE OF INDONESIAN WARSHIP (KRI)
}

\author{
Arda Widyaksa, Pompy Pratisna, Wawan Kusdiana, M. Yunus Abdullah. \\ Indonesian Naval Technology College, STTAL \\ Bumimoro-Morokrembangan, Surabaya 60187, Indonesia
}

\begin{abstract}
In carrying out these basic tasks the Navy relies heavily on the readiness of the Indonesian Warship (KRI), including the readiness of underwater construction in KRI from corrosion attack on sea water. Nowadays, KRI uses Sacrificial Anode Cathodic Protection (SACP) from corrosion attack. Whereas, SACP system has some weakness, such as the lifetime protection is short. The aim of this paper is to the analysis of Impressed Current Cathodic Protection (ICCP) design of the underwater structure of KRI using computative theory calculation and specimen test. The results of ICCP design showed that the specimens I required 0.081 Ampere (A) for protection current, specimen 2 required $0.010 \mathrm{~A}$ for protection current, specimens 3 required $0.00251 \mathrm{~A}$. With potential protection between $-800 \mathrm{mV}$ up to $-1100 \mathrm{mV}$, it described that the ICCP system is reasonable. The result of cathodic protection design towards an underwater structure of KRI (TR-40 Type) showed that 1.75 for Ampere $(A)$ and 3.35 volt $D C$ for voltage. The benefit of this paper is a reference standard in the planning of the ICCP design at KRI.
\end{abstract}

Keywords: Corrosion, Underwater Structure of Warship, Impressed Current Cathodic Protection (ICCP).

1

INTRODUCTION.

Indonesian Navy ( $\mathrm{TNI} A L)$ is the main component for maritime security. For covered maritime area, TNI AL needs Indonesian warship (KRI) (Susilo, et al., 2017). In carrying out these basic tasks the Navy relies heavily on the readiness of the Indonesian Warship (KRI), including the readiness of underwater construction in $\mathrm{KRI}$ from corrosion attack on sea water (A.S.S.Sekar, et al., 2007) (Fluge, 1997). Corrosion of metal is largely a problem for KRI (Panah \& Ajami, 2016). Corrosion is a main problem in the underwater structure material (Haroooni, et al., 2015) of KRI. Corrosion can cause degradation of product, contamination and pollution (Al-Askari, et al., 2014). Corrosion is defined as a decrease in electrochemical reaction with the environment, which involves the movement of metal ions into anode electrolyte and electrons from the metal to cathode (Emami, 2012) (AlSultani \& Nabat, 2012) (Javadi, et al., 2014). Corrosion occurred from four components must be active, likely the anode, electrolyte, cathode and metallic path (Hashim, et al., 2014).
Basically, there are five methods of corrosion control such as a change to a more suitable material, modification to the environment, use of protective coating, design modification to the system or component, and the application of cathodic or anodic protection (Roberge, 1999). Nowadays, KRI uses Sacrificial Anode Cathodic Protection (SACP) from corrosion attack. Whereas, SACP system has some weakness, such as the lifetime protection is short.

The aim of this paper is to the analysis of Impressed Current Cathodic Protection (ICCP) design on the underwater structure of $\mathrm{KRI}$ using computative theory calculation and specimen test.

Impressed Current Cathodic Protection used for larger material structures, because of that the galvanic anode can provide current for complete protection (Loto \& Popoola, 2011). ICCP gives advantage for steel material to minimize a damage from corrosion (DeGiorgi, et al., 1996). The basic component of ICCP consists of four components, such as a power source, an electrode, an electrolyte, and the structure of materials in need of 
protection (Ivanov, 2016) (Wu, et al., 2011). ICCP employs a direct current from rectifier that has the material structure of metal connected to the negative terminal from the rectifier, whereas the anode is connected to its positive terminal (Choi, et al., 2016) (Balla \& Rahmat, 2013).

Nowadays, ICCP is applied toward as ship hull, marine structures, oil and gas drill rigs, bride decks, buried pipelines and storage tanks (Baboian, 1986). ICCP at ship consists of four components, such as (1) controller/power supply, (2) reference cells $(\mathrm{Ag} / \mathrm{AgCl})$, (3) Anodes, (4) Underwater structure of the ship. It has regulated set potential levels of operation, the potential normally between $800 \mathrm{mV}$ to $-1100 \mathrm{mV}$ with $\mathrm{Ag} / \mathrm{AgCL}$ reference cell (Hogan, et al., 2005).

Boundary of problem from this paper is an ICCP system applied to the surface of the hull (underwater structure) warship at sea. Secondarily, the models in statically condition.

To support the research, this paper had many literatures, such as the Effectiveness of Impressed Current Cathodic Protection Systems in Concrete following Current Interruption (Bhuiyan, 2015). This paper explains about the effect of ICCP in reinforced concrete structures.

Corrosion: A General review (Shikhar Agarwal, 2015), The Performance of Carbon Fiber Composites as ICCP Anodes for reinforced Concrete Structures (Nguyen, et al., 2012). It explains about a possibility of carbon fiber composites used to concrete members, has been investigated as ICCP anodes. Modelling Cathodic Protection For Pipeline Networks (Riemer, 2000). The Impressed Current Cathodic Protection System (Kakuba, 2005). It explains about ICCP system and applied the system controller by PID controller and intelligent method.

ICCP Cathodic Protection of Tanks with Photovoltaic Power Supply (Janowski \& Wantuch, 2016). This paper explains about analysis of the operating parameters of ICCP with rectifier supplied from solar panels. The Application of Impressed Current Cathodic Protection for Historic Listed Reinforced Concrete and Steel Framed Structures (Broomfield, 2004). This paper explains about historic building and other structures treat with ICCP to controlling from corrosion attack. Design Optimization of Ship ICCP System (Hang \& Adey, 1999). It paper explains applied of ICCP at ship using boundary element method algorithms and search model.

This paper was organized as follows. Section 2 explains about Method and materials, consists of flowchart, Steps and goals. Section 3 explains about the result of this paper and discussion. Section 4 explains the conclusion of this paper.

\section{MATERIAL AND METHODS}

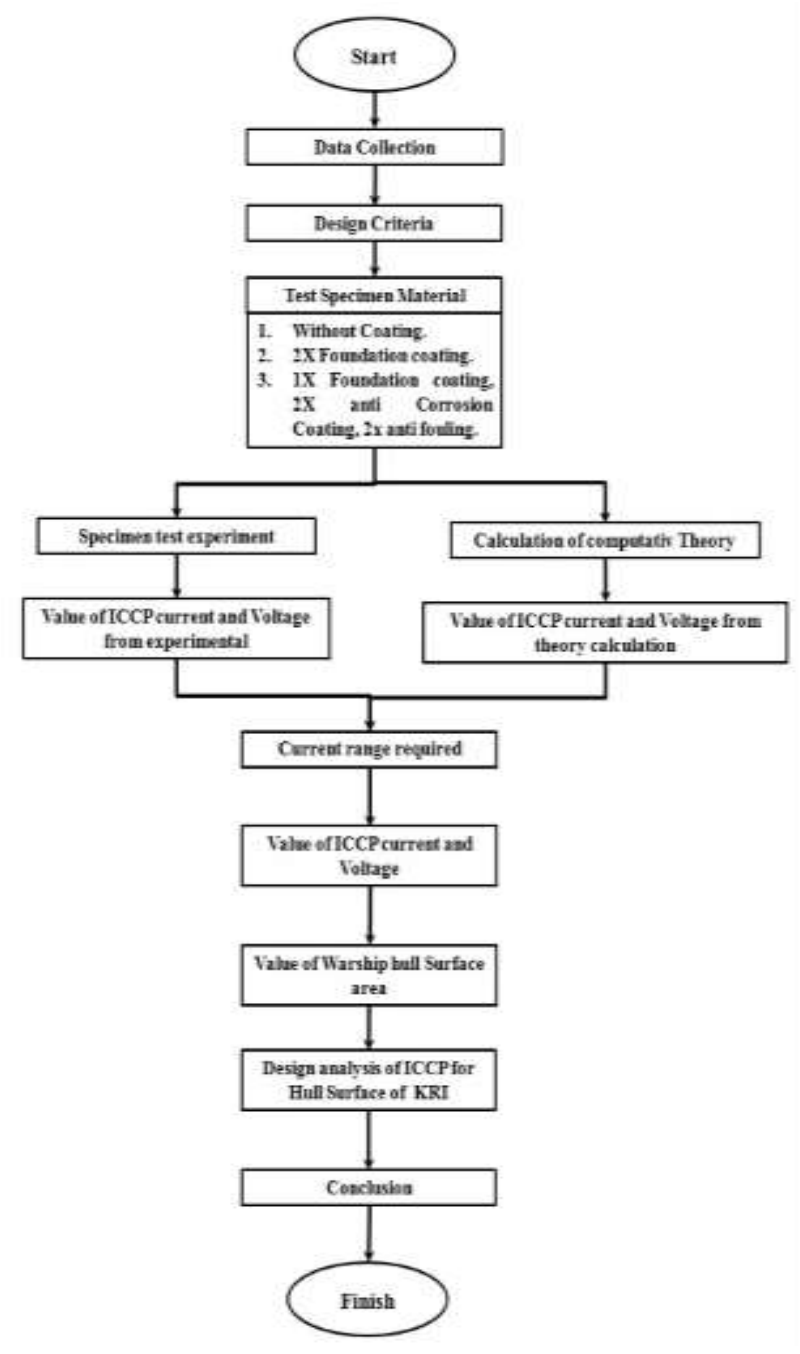

Fig.1 Flowchart of Design System 


\subsection{KRI Data}

The data of underwater structure of $K R I$ be protected: (1) Material plat: High Tension steel $\mathrm{AH}-$ 36; (2) Length over all: 46.23 meter; (3) Length of waterline: 41.4 meter; (4) Length between Perpendicular (Lbp): 40.8 meter; (5) Length Perpendicular (Lpp): 40.8 meter; (6) Length (B): 7.9 meter; (7) Draft: 1.9 meter; (8) High: 4.25 meter, (9) coefficient block (Cb): 0.39 meter.

Data of cathode is a High tension steel $\mathrm{AH}$ 36. In accordance with materials form KRI. The dimensions of specimen length $=1000 \mathrm{~mm}$, width $=$ $500 \mathrm{~mm}$, thick $=4 \mathrm{~mm}$ for 3 (three) pieces.

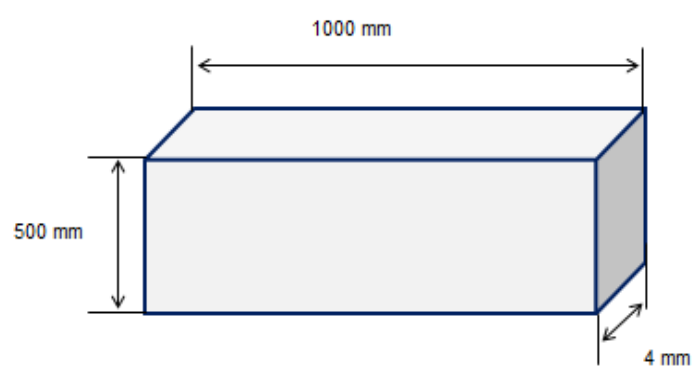

Fig.2 Illustration of Cathode Specimen

Coating of specimens using paint according to specification with thickness 80 - 350 micron, likely: (1) Specimen 1: Without paint; (2) Specimen 2 : $2 x$ foundation paint; (3) Specimen $3: 1 x$ foundation paint, 2x Anti Corrosion, 2x Anti Fouling.

Material of carbon steel plate $\mathrm{AH}-36$ has chemical composition as follows : (1) $\mathrm{C}=0.18 \%$ $(\max ) ;(2) \mathrm{Mn}=0.19 \%-1.60 \%$; (3) $\mathrm{Si}=0.1 \%$ $-0.50 \%$; (4) $\mathrm{P}=0.035 \%(\max )$; (5) $\mathrm{S}=0.035 \%$ (max) ; (6) $\mathrm{Al}=0.015 \%$; (7) Nb $=0.02 \%-0.05$ $\%$; (8) $\mathrm{V}=0.05 \%-0.1 \%$; (9) $\mathrm{Ti}=0.02 \%$; (10) $\mathrm{Cu}=0.35 \%$; (11) $\mathrm{Cr}=0.2 \%$; (12) Ni $=0.4 \%$; (13) $\mathrm{Mo}=0.08 \%$ (max) .

\subsection{Anode data}

The anode uses Titanium with the following specifications : (1) Anode material : Titanium ; (2) Anode layer : Mixed Metal Oxide (MMO) ; (3)
Anode shape : Calthelco made anode cylinder ; (4) Current capacity Maximum anode : $50 \mathrm{~A}$; (5) The length of the anode : $15 \mathrm{~cm}$; (6) Anode diameter : 2 $\mathrm{cm} ;(7)$ Consumption rate : $0,00025 \mathrm{lb} /$ A-year.

\subsection{Reference Elektode.}

(1). Mark : Staperm; (2) Type : AG-4-PT2 ; (3) Range Temperature : $32^{\circ} \mathrm{F}-135^{\circ} \mathrm{F}$; (4) Diameter : 1" dia x 8" dia; (5) Ingredients : Silver-silver/Cloride.

\subsection{Data of Coating / Protective Coating.}

The specifications of the protective layer used in accordance with the standards determined by the NACE Standard Standard RP0169-96 with the following characteristics (Peabody, 2001), likely: (1) Electrical insulator, (2) Resistance to moisture, (3) Applications, (4) Proper adhesion properties, (5) Easy ability to control, UV degradation, and installation, (6) Ability to be a constant resistance power resistance, (7) Durability of disbonding, (9) Easy to repair.

Data coatings used to protect the plate on specimens two and three namely:
a. Basic Coating: Epicon F-HB Light Gray Base
b. Anti Corrosion Paint: Rafax AC HB
c. Anti Fouling Paint : Rafax AF

\subsection{Goal.}

(1) It gives an analysis of the ICCP design of the specimen material test from underwater structure of KRI (TR-40 Class); (2) It gives an analysis of the performance of the ICCP design for underwater structure of KRI (TR-40 Class); (3) It gives an analyze of the ICCP Design for underwater structure of KRI (TR-40 Class).

\subsection{Calculation of current required.}

a. Calculation with computative theory.

b. Calculation of current required by specimen test. 


\subsection{Calculation of performance from ICCP.}

a. Calculation of performance based on potential test from DNV RP-B401.

To obtain the required current protection value, the ICCP design be given a current flowing from a DC source with a potential range of $800 \mathrm{mV}$ to -1100 $\mathrm{mV}$ from specimen test (DNV, 2010) .

b. Calculation of performance based on corrosion rate.

The corrosion rate the anodes are given by the equation below :

1) Corrosion Density

$$
\text { Icorr }=\frac{I p}{A} .
$$

2) Corrosion rate

$$
\text { Corrossion rate }=K \frac{\text { Icorr } x E}{D} \text {....(2) }
$$

Where:

$$
\begin{array}{ll}
\text { Icorr } & =\text { Corrossion density } \\
\mathrm{Ip} & =\text { The distance between anodes }(\mathrm{m}) \\
\mathrm{A} & =\text { Surface area } \\
\mathrm{K} & =0,1288(\mathrm{mpy} \text { gram } / \mu \mathrm{Acm}) \\
\mathrm{E} & =\text { Equivalent weight }(\mathrm{gram} / \mathrm{mol} . \mathrm{eq}) \\
\mathrm{D} & =\text { Specific Gravity }\left(\mathrm{g} / \mathrm{cm}^{3}\right)
\end{array}
$$

\section{c. Corrosion rate.}

Table 1. Value of Corrosion Rate (Fontana, 1987)

\begin{tabular}{|c|c|c|c|c|c|}
\hline \multirow{2}{*}{$\begin{array}{c}\text { Relative Corrosin } \\
\text { Resistance }\end{array}$} & \multicolumn{5}{|c|}{ Approximate Metric Equivalent } \\
\cline { 2 - 6 } & $\mathrm{mpr}$ & $\mathrm{mm} / \mathrm{yr}$ & $\mu \mathrm{m} / \mathrm{r}$ & $\mathrm{nm} / \mathrm{yr}$ & $\mathrm{pm} / \mathrm{s}$ \\
\hline Outstanding & 4 & $<0,02$ & $<25$ & $<2$ & $<1$ \\
\hline Exeallent & $1-5$ & $0,02-0,1$ & $25-100$ & $2-10$ & $1-5$ \\
\hline Good & $5-20$ & $0,1-0,5$ & $100-500$ & $10-50$ & $5-20$ \\
\hline Fair & $20-50$ & $0,5-1$ & $500-1000$ & $50-150$ & $20-50$ \\
\hline Poor & $50-200$ & $1-5$ & $1000-5000$ & $150-500$ & $50-200$ \\
\hline
\end{tabular}

\subsection{Theoretical calculation of ICCP design at} KRI (TR-40 Type).

It has many steps to design of ICCP system, such as (NACE, 2002) : (1) Surface of wetted area,
(2) Current protection required, (3) Current of anode, (4) Required of total anode, (5) single anode resistance, (6) Wire resistance, (7) Requirement voltage of the rectifier.

\subsection{Tools.}

The tools are used for this research, such as (1) Transformer Rectifier, (2) multimeter, (3) electrode reference Silver-silver/Cloride, (4) Titanium anode (MMO).

\section{RESULTS AND DISCUSSION}

\subsection{Calculation of current required.}

a. Calculation with computative theory.

Calculation of the ICCP value of the specimen based on theory by using a formula to calculate the actual specimen plate, with the calculation obtained the current value based on the paint treatment on the specimen used.

Calculation on specimen 1 with treatment of paint plate without coating breakdown factor $(\mathrm{Cb})$ $100 \%$ based on calculation got result according to table 2.

Table 2. Result of calculation of Theory from specimen 1. 


\begin{tabular}{|c|c|c|c|c|}
\hline & $\begin{array}{c}\text { DESIGN } \\
\text { CALCULATION }\end{array}$ & CALCULATION FORIMULA & RESULT & UNT \\
\hline 1 & Surfice Area & $2 \times 1 \times \times 1$, fit & 1 & $\pi^{2}$ \\
\hline 2 & Curent required & $\mathrm{Ip}=1 \mathrm{~m}^{\mathrm{x}} \times 0,07 \frac{A}{\mathrm{~m}^{2}} \times 1 \mathrm{x}(1+0,15)$ & 0.081 & A \\
\hline 3 & $\begin{array}{l}\text { Densty of ansde } \\
\text { current }\end{array}$ & $\log 15=3,3-\log L_{2}$ & 133,17 & $A / m^{2}$ \\
\hline 4 & \begin{tabular}{|l|} 
Anode Surfiece Area \\
(Ag)
\end{tabular} & $\mathrm{k}=3,14=0,0254 \mathrm{~m} \times \mathrm{B}, 1 \mathrm{~m}$ & 0,0079 & $\pi^{2}$ \\
\hline 5 & \begin{tabular}{|l|} 
The nunter of \\
gnodes required (M)
\end{tabular} & $N=\frac{0,031 A}{133,017 d / \mathrm{rr}^{2} \times 0,0075}$ & $0,07758 \times 1$ & Anodi \\
\hline 6 & Anoda Resitance & $D s=\frac{0,19(2,1 \pi)}{2 \pi x 0,1 \pi} \times\left(\left(\ln \frac{4(0,1)}{0,12127}\right)-1\right)$ & 1,16 & 0 \\
\hline 7 & DC Cable Pasistance & $R_{z}=\frac{30 \mathrm{~m} \times 100030 \frac{2}{\pi}}{1 \times 1}$ & 0,0924 & 0 \\
\hline 8 & $\begin{array}{l}\text { Totel OC circul } \\
\text { resistance }\end{array}$ & $\mathrm{R}=1,150 \mathrm{a}+0,0 \mathrm{cou} \mathrm{a}$ & 0,866 & 0 \\
\hline 9 & DC Yatage Recitier & $\left.V_{k}=\left((0,081 A x 0,773 a) x_{1}^{\prime} 1+0,20\right]\right)+2 V$ & 2,12 & $\gamma$ \\
\hline 10 & $\begin{array}{l}\text { AC input carrert } \\
\text { required }\end{array}$ & $l_{\mathrm{s}}=\frac{0,081 \mathrm{~A} \times 2 \mathrm{~V}}{2207 \mathrm{~V} \times 0,8 \mathrm{r} \sqrt{3}}$ & 0,000256 & $A$ \\
\hline 11 & $\begin{array}{l}\text { The required ingut } \\
\text { rotgge }\end{array}$ & $P_{s e}=0,0005454 \times 202 \mathrm{~V} x \sqrt{3}$ & 0,213 & $W$ \\
\hline
\end{tabular}

Calculation on specimen 2 with plate treatment 2 (Two) layers of coat base with coating breakdown factor $(\mathrm{Cb}) 13 \%$ based on calculation got result according to the table. 3 .

Table 3. Result of calculation of Theory from specimen 2.

\begin{tabular}{|c|c|c|c|c|}
\hline & $\begin{array}{c}\text { DESSIGH } \\
\text { CALCULATIDE }\end{array}$ & CALCULATIOA FORLULA & RESULT & เผี \\
\hline 1 & Sarface Area & $2 \times 1 n \times 0.00$ & 2 & $\pi$ \\
\hline 2 & Garrent requires & 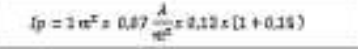 & oosa & $\wedge$ \\
\hline 3 & Densily af anabe cirrent & $\log 18=a 2-\log 0$ & 138,17 & $\mathrm{Nm}$ \\
\hline 4 & $\begin{array}{l}\text { Antodo Surbes Aras } \\
\text { (A.) }\end{array}$ & $2 a=2,34 \cdot 2,025+2 \cdot 0 \cdot 0,=$ & 0,095 & $\boldsymbol{m}^{2}$ \\
\hline 5 & $\begin{array}{l}\text { The number of onides } \\
\text { requeres (N) }\end{array}$ & 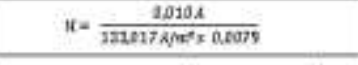 & $0.0657 \div 1$ & Anofo \\
\hline 5 & Anrda Fesiatarce & 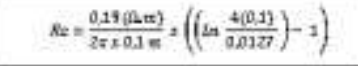 & 1,16 & A \\
\hline 7 & OC Cable Rasatance & $A_{c}=\frac{30 n \times 0.002018 \frac{n}{n}}{1 \times 1}$ & 0,0424 & n \\
\hline a & $\begin{array}{l}\text { Toral DC ciecut } \\
\text { cesiotanco }\end{array}$ & Fit $=1,160 \mathrm{~N}+0,0324 \mathrm{n}$ & 1,83 & n \\
\hline 9 & oc Votsye fiectifer & $V_{40}=\{(0,10 A \times 20924 a) \times(1+0,20)\}+2 \mathrm{~V}$ & 2,015 & v \\
\hline 10 & $\begin{array}{l}\text { AC input sulrent } \\
\text { requiret }\end{array}$ & 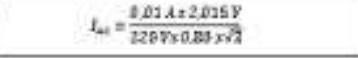 & asessis & a \\
\hline 11 & $\begin{array}{l}\text { The regured inpat } \\
\text { votags }\end{array}$ & 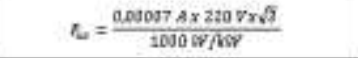 & gaséc & $\mathrm{w}$ \\
\hline
\end{tabular}

Calculation on specimen 3 with treatment of plate 5 (Five) layers of coat with coating breakdown factor $(\mathrm{Cb}) 3,1 \%$ based on calculation got result according to the table. 4
Calculation on specimen 3 with treatment of plate 5 (Five) layers of coat with coating breakdown factor $(\mathrm{Cb}) 3,1 \%$ based on calculation got result according to the table. 4 .

Table 4. Result of calculation of Theory from specimen 3.

\begin{tabular}{|c|c|c|c|c|}
\hline & $\begin{array}{c}\text { DESIGN } \\
\text { CALCULATION }\end{array}$ & CALCULATION FORMULA & RESULT & UNIT \\
\hline 1 & Surtace Area & $2 \times 1 \mathrm{~m} \times 0.5 \mathrm{~m}$ & 1 & $m^{*}$ \\
\hline 2 & Cument required & $I_{P}=1 \mathrm{~m}^{2} \times 0.07 \frac{\mathrm{A}}{\mathrm{m}^{2}} \times 0.031 \times(1+0.15)$ & 0.00250 & A \\
\hline 3 & $\begin{array}{l}\text { Density of anode } \\
\text { current }\end{array}$ & $\log 15=3.3-\log 4_{4}$ & 135,17 & $\mathrm{~A} / \mathrm{m}^{2}$ \\
\hline 4 & $\begin{array}{l}\text { Anode Surtace Area } \\
\left(A_{0}\right)\end{array}$ & $\mathrm{As}=3.14=0.0254 \mathrm{~m} \sim 0.10 \mathrm{~m}$ & 0,0079 & $m^{2}$ \\
\hline 5 & $\begin{array}{l}\text { The number of anodes } \\
\text { required (N) }\end{array}$ & $\mathrm{N}=\frac{0,0025 \mathrm{~A}}{\left[39.017 \mathrm{~A} / \mathrm{m}^{2} \times 0.007 \%\right.}$ & $0,0023 * 1$ & Anode \\
\hline 0 & Anoda Resistance & $R a=\frac{0,19(\mathrm{\Omega} m)}{2 \pi \times 0,1 \mathrm{~m}} \times\left(\left(2 n \frac{4(0,1)}{0,0127}\right)-1\right)$ & 1.16 & $\Omega$ \\
\hline 7 & DC Cable Resiatanco & $R_{1}=\frac{30 \mathrm{~m} \times 0.00300_{m}^{O}}{1 \times 1}$ & 0,0924 & $n$ \\
\hline 8 & $\begin{array}{l}\text { Total DC circuit } \\
\text { resistance }\end{array}$ & Rt $=1,16 \mathrm{n}+0,0924 \mathrm{n}$ & 1,259 & $\Omega$ \\
\hline 9 & DC Voltage Reotifier & $V_{\Delta t}=((0,0025 A \times 12.53 \Omega) \times(1+0,2))$ & 2005 & $v$ \\
\hline 10 & $\begin{array}{l}\text { AC input carrent } \\
\text { required }\end{array}$ & $I_{A C}=\frac{0,0025 \mathrm{~A} \times 2 \mathrm{~V}}{220 \mathrm{~V} \times 0.00 \times \sqrt{3}}$ & 0,00002 & A \\
\hline 11 & $\begin{array}{l}\text { The required input } \\
\text { voltage }\end{array}$ & $P_{a r}=\frac{0,00002 . A \times 220 \mathrm{Vx} \sqrt{\mathrm{a}}}{1000 \mathrm{~W} / \mathrm{kW}}$ & 0.0076 & $\mathrm{~kW}$ \\
\hline
\end{tabular}

The average current is then analyzed for its compatibility with the calculation and design of the area. The calculation of the design analysis involves the calculation of the plate design, the type of paint protection, the type of sacrificial anode used and the value of stress required in making the Transformer Rectifier design. The data taken are also used to analyze how the performance of the ICCP (Impressed Current Cathodic Protection) devices against their performance in $\mathrm{AH}-36$ steel plate protection against corrosion.

Based on the three specimen tables above, the difference in the value of the coating breakdown factor is very influential on the value of protection current required in each specimen calculation, so that the value of protection current required in each specimen based on the level of paint layer provided.

Table 5. Specimen current value

\begin{tabular}{|c|c|c|c|c|}
\hline NAME & $\begin{array}{c}\text { SPECIMEN 1 } \\
\text { (Without Paint) }\end{array}$ & $\begin{array}{c}\text { SPECIMEN 2 } \\
\text { (2 } \mathrm{x} \text { Paint) }\end{array}$ & $\begin{array}{c}\text { SPECIMEN 3 } \\
\text { (5x Paint) }\end{array}$ & UNIT \\
\hline CURRENT & 0,081 & 0,010 & 0,0025 & $\mathrm{~mA}$ \\
\hline
\end{tabular}




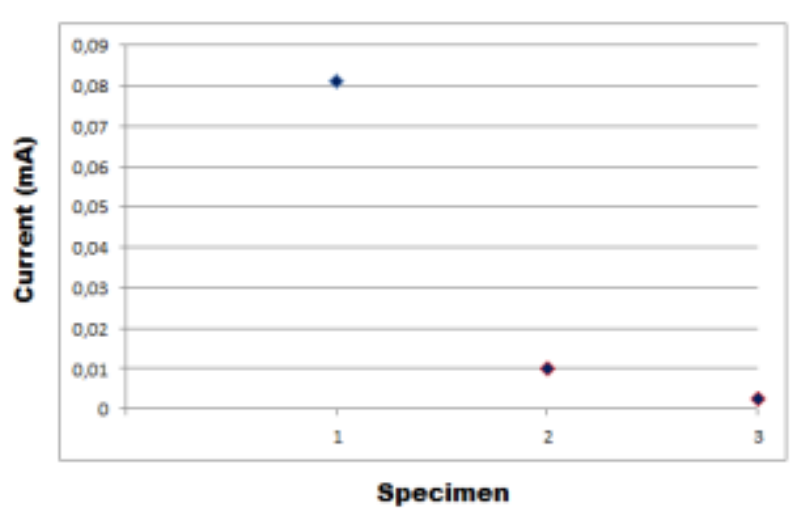

Fig.3 Value of Current from Specimen

Based on Table 5 and Figure 4 the value of protection current required for specimens 1,2 and 3 shows different values. The difference lies in each of the protected layer conditions used, there is a decrease in the current protection value of specimen 3 from $0.010 \mathrm{~mA}$ with the highest value in specimen1 with a current value of $0.081 \mathrm{~mA}$ in $\mathrm{DC}$ current.

b. Calculation of current required by specimen test.

The tests were performed by manual measurement as preliminary data to be adjusted to potential measurable protection criteria in accordance with Dot Norske Veritas (DNV RPB401), 1993. Basic Potential Value of Specimen Plat.

Table 6. The basic potential value of the specimen

\begin{tabular}{|c|c|c|c|c|}
\hline NAME & $\begin{array}{c}\text { SPECIMEN } 1 \\
\text { (Without Paint) }\end{array}$ & $\begin{array}{c}\text { SPECIMEN } 2 \\
\text { (2x Paint) }\end{array}$ & $\begin{array}{c}\text { SPECIMEN } 3 \\
\text { (5x Paint) }\end{array}$ & UNIT \\
\hline Potential & $-0,584$ & $-0,943$ & $-1,003$ & v \\
\hline
\end{tabular}

Table 7. The basic potential anode

\begin{tabular}{|c|c|c|c|c|}
\hline NAME & $\begin{array}{c}\text { SPECIMEN 1 } \\
\text { (Without Paint) }\end{array}$ & $\begin{array}{c}\text { SPECIMEN 2 } \\
\text { (2x Paint) }\end{array}$ & $\begin{array}{c}\text { SPECIMEN 3 } \\
\text { (5 } \times \text { Paint) }\end{array}$ & UNIT \\
\hline Potential & $-0,366$ & $-0,364$ & $-0,353$ & $\mathrm{~V}$ \\
\hline
\end{tabular}

Table 8. The current value of specimen test protection

\begin{tabular}{|c|c|c|c|}
\hline \multicolumn{2}{|c|}{ Specimen 1 } & Specimen 2 & Specimen 3 \\
\hline DAY & $\begin{array}{c}\text { CURRENT VALUE } \\
(\mathrm{mA})\end{array}$ & $\begin{array}{c}\text { CURRENT VALUE } \\
(\mathrm{mA})\end{array}$ & $\begin{array}{c}\text { CURRENT VALUE } \\
(\mathrm{mA})\end{array}$ \\
\hline 1 & 77,00 & 8,00 & 2,35 \\
2 & 79,00 & 9,00 & 2,43 \\
3 & 80,00 & 10,00 & 2,49 \\
4 & 80,00 & 10,00 & 2,50 \\
5 & 80,00 & 10,00 & 2,50 \\
6 & 81,00 & 10,00 & 2,50 \\
7 & 81,00 & 10,00 & 2,50 \\
8 & 81,00 & 10,00 & 2,51 \\
9 & 81,00 & 10,00 & 2,51 \\
10 & 81,00 & 10,00 & 2,51 \\
11 & 81,00 & 10,00 & 2,51 \\
12 & 81,00 & 10,00 & 2,51 \\
13 & 81,00 & 10,00 & 2,51 \\
14 & 81,00 & 10,00 & 2,51 \\
& & & \\
\hline
\end{tabular}



Fig.4 Graph of the current value of specimen test protection

Based on Table 8, specimen test 1, it is known that the current value is $77 \mathrm{~mA}$ at the initial condition, while the highest current value $81 \mathrm{~mA}$ then tends to be constant. In testing specimen 2 it is known that the current value is $8 \mathrm{~mA}$ at the initial condition, while the highest current value is $10 \mathrm{~mA}$ and the current value tends to be constant. In the test of specimen 3 it is known that the current value is $2.35 \mathrm{~mA}$ at the initial condition, while the highest current value of $2.51 \mathrm{~mA}$ then tend to be constant.

From Figure 5 specimen 1 has the highest protection current rating than specimens 2 and 3 of $81 \mathrm{~mA}$. This is because the metal will immediately corrode if there is direct contact with the sea water environment. In the corrosion process the electron (oxidation) produces a large current to resist the oxidation current, whereas in specimens 2 and 3 the metal is protected by the coating layer so that 
the protection system only covers the imperfect metal coating. Structures protected by a good paint layer will have a smaller current value, the greater the current the greater the value of damage to the protected layer of the specimen to the highest current is the condition without the protection layer.

c. The relationship between the theoretical current value and the test current

Based on data from Table 9 and Figure 6, the theoretical current values for the test currents in the specimen 1 pipes that do not use the protective layer and the 2 specimens with two paints according to the calculations are $81 \mathrm{~mA}$ and $10 \mathrm{~mA}$, whereas in specimen 3 , the current test has increased the value of a very small current that is $0.00001 \mathrm{~A}$.

Table 9. The value of current from specimen test and calculation theory.

\begin{tabular}{|c|c|c|c|}
\hline Name & $\begin{array}{c}\text { Current } \\
\text { Thoery }\end{array}$ & $\begin{array}{c}\text { Test } \\
\text { current }\end{array}$ & Unit \\
\hline $\begin{array}{c}\text { Specimen 1 } \\
\text { (Without paint) }\end{array}$ & 0,081 & 0,081 & $\mathrm{~A}$ \\
\hline $\begin{array}{c}\text { Specimen 2 } \\
\text { (2x paint) }\end{array}$ & 0,01 & 0,010 & $\mathrm{~A}$ \\
\hline $\begin{array}{c}\text { Specimen 3 } \\
\text { (5xpaint) }\end{array}$ & 0,0025 & 0,00251 & $\mathrm{~A}$ \\
\hline
\end{tabular}

Table 10. Deviation Error

\begin{tabular}{|c|l|r|r|r|}
\hline No & \multicolumn{1}{|c|}{ Name } & Specimen 1 & Specimen 2 & Specimen 3 \\
\hline 1 & Mean & 80,42557143 & 9,785724286 & 2,488571429 \\
2 & Deviasi Errot & 0,326726786 & 0,15472665 & 0,012037357 \\
\hline 3 & Median & 81 & 10 & 2,505 \\
4 & Mode & 81 & 10 & 2,51 \\
5 & Standard Deviation & 1,222499691 & 0,578934224 & 0,045039665 \\
6 & Sample Variance & 1,494505495 & 0,335164835 & 0,002028571 \\
7 & Kurtosis & 4,344791994 & 7,679113517 & 7,520200787 \\
8 & Skewness & $-1,870564649$ & $-2,803342338$ & $-2,737445042$ \\
9 & Mange & 5 & 2 & 0,16 \\
10 & Minimum & 77 & 8 & 2,35 \\
11 & Maximum & 82 & 10 & 2,51 \\
12 & Sum & 1126 & 137 & 34,84 \\
13 & Count & 14 & 14 & 14 \\
\hline
\end{tabular}

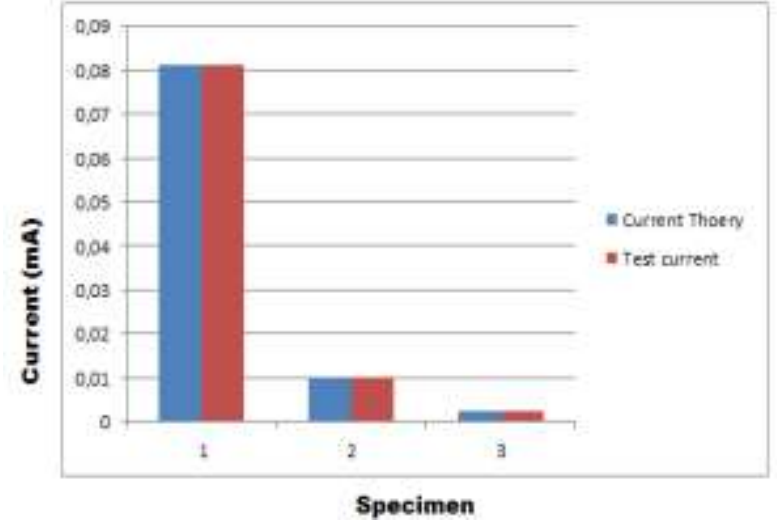

Fig.5 Graph of current values

In specimens 1 and 2, the test stream corresponds to the current at the calculation, but in specimen 3 there is a small increase of current from the calculation and the direct test is affected by the current in the seawater and the quality of the protective layer itself. In Table 10, specimens 1.2, and 3 , the error deviations indicating below $0.5 \%$ indicates the accuracy of the data and the ICCP test tool is reasonable.

\subsection{Calculation of performance from ICCP.}

a. Calculation of performance based on potential test from DNV RP-B401.

In tests using the ICCP (Impressed Current Cathodic Protection) tool on specimens 1,2 and 3 to obtain the required current protection value, a current flowing from a DC source with respect to the corresponding potential range of $800 \mathrm{mV}$ to $1100 \mathrm{mV}$ is obtained in table 10 and figure 7.

Table 11. The value of current from specimen

\begin{tabular}{|c|c|c|c|c|c|}
\hline \multicolumn{2}{|c|}{ Specimen 1 } & \multicolumn{2}{c|}{ Specimen 2 } & \multicolumn{2}{c|}{ Specimen 3 } \\
\hline $\begin{array}{c}\text { CURENT } \\
\text { VALUE }\end{array}$ & $\begin{array}{c}\text { POTENTIAL } \\
\text { VALUE }\end{array}$ & $\begin{array}{c}\text { CURENT } \\
\text { VALUE }\end{array}$ & $\begin{array}{c}\text { POTENTIAL } \\
\text { VALUE }\end{array}$ & $\begin{array}{c}\text { CURENT } \\
\text { VALUE }\end{array}$ & $\begin{array}{c}\text { POTENTIAL } \\
\text { VALUE }\end{array}$ \\
\hline$(\mathrm{mA})$ & $(\mathrm{mV})$ & $(\mathrm{mA})$ & $(\mathrm{mV})$ & $(\mathrm{mA})$ & $(\mathrm{mV})$ \\
\hline 77,00 & 851,00 & 7,00 & $1.043,00$ & 2,35 & $1.049,00$ \\
79,00 & 854,00 & 8,00 & $1.048,00$ & 2,43 & $1.051,00$ \\
80,00 & 856,00 & 9,00 & $1.051,00$ & 2,49 & $1.058,00$ \\
81,00 & 858,00 & 10,00 & $1.053,00$ & 2,50 & $1.060,00$ \\
& & & & 2,51 & $1.062,00$ \\
& & & & & \\
\hline
\end{tabular}




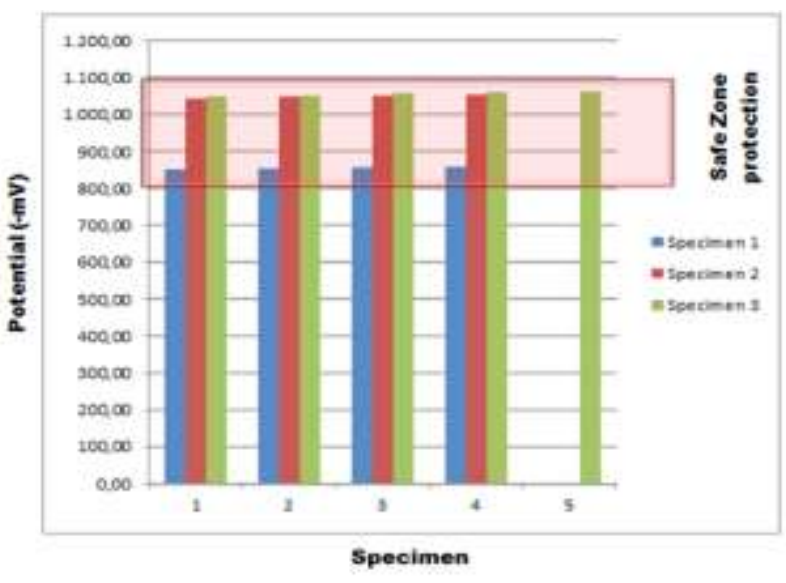

Fig.6 Graph of current values from specimen test

Based on Table 11 and Figure 7, the ICCP Transformer Rectifier tool rated current values are specimens $1(80 \mathrm{~mA})$, specimens $2(10 \mathrm{~mA})$, and specimen $3(2.51 \mathrm{~mA})$. According to the result of current test for potential in specimens 1,2 and 3 corresponding to the range of potential criteria measured according to Dot Norske Veritas (DNV RP-B401) 1993, between $-800 \mathrm{mV}$ to $-1100 \mathrm{mV}$, it can be said that the performance of the device against the value of the test current has been able to protecting the plate from corrosion.

b. Calculation of performance based on corrosion rate.

To determine the value of the corrosion rate of the plate, use the formula 1 with the follow-up formula 2 in which the carbon steel weight is known to be $7.84 \mathrm{~g} / \mathrm{cm}^{3}$, and the weight equivalent of the steel with $\mathrm{Fe} \rightarrow \mathrm{Fe}^{3+}+3 e^{-}$composition of $18.62 \mathrm{~g} /$ mol.eq. With a surface area of $1 \mathrm{~m}^{2}$ specimen and surface area below the waterline of $\mathrm{KRI} 686,057 \mathrm{~m}^{2}$, hence got a value of corrosion rate and criteria according to table 12 .

Table 12. Value of Corrossion

\begin{tabular}{|c|c|c|}
\hline Name & $\begin{array}{c}\text { Test } \\
\text { Current (A) }\end{array}$ & $\begin{array}{c}\text { Corrossion } \\
\text { rate (mpy) }\end{array}$ \\
\hline $\begin{array}{c}\text { Specimen 1 } \\
\text { (without pain) }\end{array}$ & 0,081 & $2,4 / 1$ \\
\hline $\begin{array}{c}\text { Spccimon 2 } \\
\text { (2x Paint) }\end{array}$ & 0,01 & 0,305 \\
\hline $\begin{array}{c}\text { Specimen 3 } \\
\text { (5xPaint) }\end{array}$ & 0,00251 & 0,076 \\
\hline
\end{tabular}

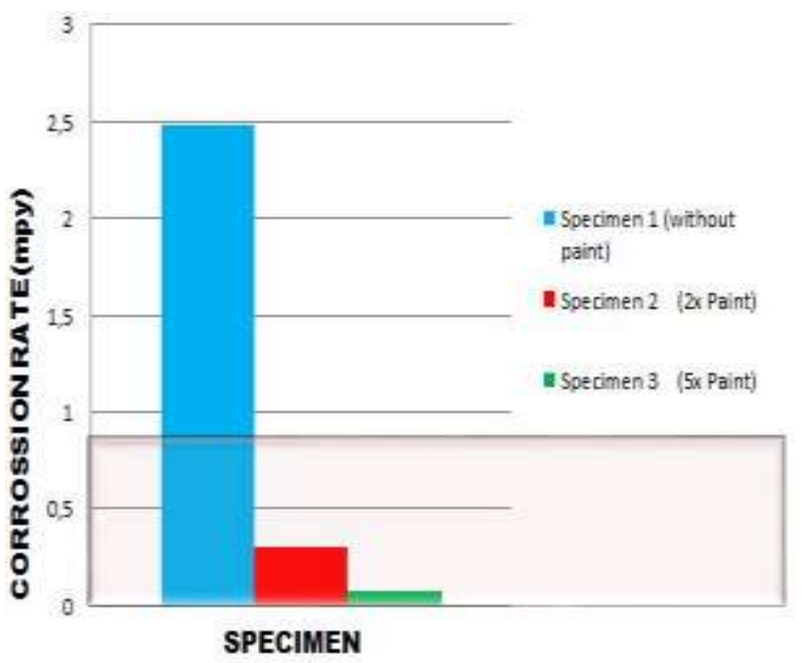

Fig.7 Value of Corrossion rate

Based on Table 12 in Figure 8, it can be seen that the performance of ICCP devices with excellent corrosion rate of specimens 1 and 2 categories $(<1)$ and 3 specimens in a good category $(1-5)$ and the value of corrosion rate on design with current $1.75 \mathrm{~A}$ and The area of 686,057 $\mathrm{m} 2$ with the corrosion rate value of 0.076 mpy enter in the very good category.

\subsection{Theoretical calculation of ICCP design at KRI (TR-40 Type).}

The calculation design of the ICCP protection system is done by using a series of formulas and steps that have been planned previously. In this plan use predetermined standards and limitations that have been established also to obtain the expected results. In the calculation of this design obtained results to determine the value of current required for the use of ICCP circuit, the results obtained in accordance with table 1.7 below.

From the data table 8 , it is known the value of protection flow needed for protection on the water line $\mathrm{KCR} 40 \mathrm{~m}$ is equal to $1.712 \mathrm{~A}$ with the surface area of the sea water line is protected for $686,057 \mathrm{~m} 2$. In Table 13, it can be seen the ICCP system design results in $\mathrm{KRI}$ 
Table 13. Calculation Design of ICCP for underwater Structure of Warship

\begin{tabular}{|c|c|c|c|c|}
\hline & $\begin{array}{c}\text { DESIGN } \\
\text { CALCULATION }\end{array}$ & CALCULATION FORLULA & RESULT & UNIT \\
\hline 1 & Surface Area & w54. $1.725(\langle 1.75 n s)+(0.7 \times 4.25) \times 40.7 m$ & GaE, $08 ?$ & $m^{2}$ \\
\hline 2. & Current requied & $y=68.057 \mathrm{~m}^{2} x .0 .07 \frac{1}{\pi \pi^{2}} \times 0.031 x(1+0.15)$ & 1,712 & A \\
\hline 3 & $\begin{array}{l}\text { Density of anode } \\
\text { cuirrent }\end{array}$ & $\operatorname{let} 15=13-\operatorname{lat} 6$ & 1213,87 & $\mathrm{~A} / \mathrm{m}^{x}$ \\
\hline 4 & $\begin{array}{l}\text { Anode Sufface Hea } \\
\text { (A) }\end{array}$ & 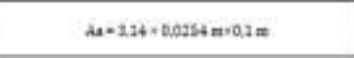 & 0,0008 & $\operatorname{rr}^{2}$ \\
\hline 5 & $\begin{array}{l}\text { The number of anodes } \\
\text { required (N) }\end{array}$ & $N=\frac{1.7212 A}{133,617 A / m^{1} \times 00079}$ & $162: 3 * 2$ & Anoda \\
\hline 6 & Anoda Resistarce & $\Delta a=\frac{0.19(2 \pi)}{2 \pi+0.1 m}=\left(\left(L-\frac{4(01)}{0.0177}\right)-1\right)$ & 1,1006 & a \\
\hline 7 & CC Cable Resistance & $A_{t}=\frac{50 m \times 0.00300 \frac{A}{s}}{1.1}$ & 0,154 & n \\
\hline B. & $\begin{array}{l}\text { Total DC crouli } \\
\text { resistance }\end{array}$ & 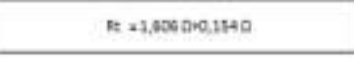 & 1.,134 & a \\
\hline 9 & DC Vollage Rectifer & $V_{c}=(1.712 .4 \times 11666 a) \times(1+0.30 j)+2 v$ & 3,35 & $v$ \\
\hline 10 & $\begin{array}{l}\text { AC inpe current } \\
\text { regared }\end{array}$ & 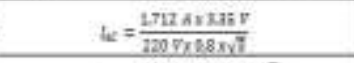 & 9,018 & A \\
\hline 11 & $\begin{array}{l}\text { The required inpat } \\
\text { wollags }\end{array}$ &  & 6.858 & $\mathrm{w}$ \\
\hline
\end{tabular}

Table 14. Calculation Design of ICCP

\begin{tabular}{|c|c|c|c|}
\hline & \multicolumn{3}{|c|}{$\begin{array}{l}\text { Sytem design ICCP KCR } 40 \text { m ( KRI TRP - } 648 \text { Case } \\
\text { Study) }\end{array}$} \\
\hline & Description & Value & Unit \\
\hline \multirow{8}{*}{$\begin{array}{l}\mathbf{1} \\
2 \\
3 \\
\mathbf{4} \\
5 \\
\mathbf{6}\end{array}$} & \multicolumn{3}{|c|}{ Protected structure } \\
\hline & Structure Type & KRI TRP - G4E & \\
\hline & Dlock Cootisien (Cb) & 0.39 & . \\
\hline & LwI KRI & 41.4 & $m$ \\
\hline & Moulded & 1.9 & $m$ \\
\hline & Wide Moulded & 7.9 & $m$ \\
\hline & Wetted area & 686.067 & $m^{2}$ \\
\hline & \multicolumn{3}{|c|}{ Protect design criteria } \\
\hline \multirow{4}{*}{$\begin{array}{l}8 \\
9\end{array}$} & Level of protection & Silver-silver c & \\
\hline & Lower limit & -800 & $m v$ \\
\hline & \multirow{2}{*}{\multicolumn{3}{|c|}{ Basic data dasign }} \\
\hline & & & \\
\hline 10 & Total current protection & 1.712 & A \\
\hline 11 & Environment & Madura strait & \\
\hline \multirow{2}{*}{$\begin{array}{l}12 \\
13\end{array}$} & Goating Ereakdown & 3. 1 & $A / m^{a}$ \\
\hline & \multicolumn{3}{|c|}{ ICCP anode data } \\
\hline & Anode type & Fitanium - Mix & fetai Oxide \\
\hline 15 & Anode substrate material & Grade $t$ Titan & \\
\hline 16 & Anode coating material & Mixed Motal C & \\
\hline 17 & Age of anode design & 16 & years \\
\hline 18 & Anode shape & Tubular & \\
\hline 19 & Anode diameter & 2.54 & $\mathrm{~cm}$ \\
\hline 20 & The lenght of anode & 15 & $m$ \\
\hline 21 & Number of anode & & ва \\
\hline \multirow{6}{*}{$\begin{array}{l}22 \\
23 \\
21 \\
25 \\
26\end{array}$} & \multicolumn{3}{|c|}{ Cable data } \\
\hline & croes eoction of catio & $\frac{\mathrm{g}}{20}$ & לירורוו \\
\hline & Catsin Iminght & 100 & $m$ \\
\hline & Duble spocific resistunce & 0.00308 & Ghorn/m \\
\hline & \multirow{2}{*}{\multicolumn{3}{|c|}{ Transformer rectifer }} \\
\hline & & & \\
\hline 27 & Typu TR & Power supply & $10 \mathrm{~A}$ \\
\hline 20 & Number & 1 & \\
\hline 30 & Sintaty ta & גניכ: & $\mathrm{m}$ \\
\hline 31 & $\begin{array}{l}\text { Bach vultanu } \\
\text { Effeciency TR }\end{array}$ & 00 & 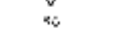 \\
\hline 37 & Sutput voltage & is ats & $\checkmark$ \\
\hline 3.3 & CuIthI pruthitiun & 1.712 & A \\
\hline 34 & Dapacity / $A D$ power supply & 6.050 & kW \\
\hline jo & AC input curront & 0.010 & A \\
\hline
\end{tabular}

\section{CONCLUSION}

The results of ICCP tool design made between the theory flows and test currents on the specimens are relatively similar the specimens I require a $0.081 \mathrm{~A}$ protection current, specimen 2 requires a $0.010 \mathrm{~A}$ protection current, and the three specimens require a current of $0.00251 \mathrm{~A}$ at potential between $-800 \mathrm{mV}-1100 \mathrm{mV}$. The result of the design of cathodic protection system of forced gastric flow method underwater line, at KRI (TR-40
Type) required a forced flow of $1.75 \mathrm{~A}$ with a voltage of 3.35 volts DC. This ICCP design system is reasonable used for Indonesian Warship (KRI).

\section{REFERENCES}

A.S.S.Sekar, V.Saraswathy \& G.T.Parthiban, 2007. Cathodic Protection of Steel in Concrete Using Conductive Polymer Overlays. International Journal of Electrochemical Science, pp. 872-882.

Al-Askari, Liptakova, T., Fajnor, P. \& Halamova, M., 2014. Mechanical Surface Treatments Effects on Corrosion of AISI 316 Ti Stainless Steel in Chloride Environments. Journal of Engineering Research, 2(3), pp. 196-212.

Al-Sultani, K. F. \& Nabat, J. N., 2012. Protect of Underground Oil Pipelines by Using (Al-Sn$\mathrm{Zn}$ ) as Sacrificial Anode in Al-Qasim Region. Journal of American Science, pp. 158-165.

Baboian, R., 1986. Miniaturised Impressed Current Corrosion Protection Systems. Platinum Metals Rev, Volume 30, pp. 63-67.

Balla, E. E. \& Rahmat, M. F., 2013. System Identification Modelling and IMC Basic Control of Impressed Current Cathodic Protection Systems. International Journal on Smart Sensing and Intelligent System.

Bhuiyan, S., 2015. Effectivenes of Impressed Current Cathodic protection Systems in Concrete following Current Interruption, London: RMIT university.

Broomfield, J. P., 2004. The application of impressed current cathodic. JCSE.

Choi, B., Kim, J. \& Oh, J., 2016. Cathodic Protection of Onshore Buried Pipelines Considering Economic Feasibility and Maintenance. Journal of Advanced Research in Ocean Engineering.

DeGiorgi, V. G., Thomas, E. D., Lucas, K. E. \& Kee, A., 1996. A Combine Design Methodology for Impressed Current Cathodic Protection System. Transaction of Modelling and Simulation, Volume 13, pp. 336-344.

DNV, R. P., 2010. Cathodic Protection Design. Hovik: Det Norske Veritas Industry Norway AS.

Emami, M. R. S., 2012. An Experimental and theoritical Investigation of Corrosion Mechanism in A Metallic Stack. Iranian 
Journal of Material Science \& Engineering, 9(3), pp. 58-66.

Fluge, F., 1997. Environment Loads on Coastal Brigde. Proceeding of the International Conference on Repair of Concrete Structures, pp. 89-98.

Fontana, M. G., 1987. Corrosion Engineering. Singapore: McGraw Hill,Inc.

Hang, P. Y. \& Adey, R. A., 1999. Design Optimisation of Ship ICCP System. Transactions on Modelling and Simulation, Volume 24, pp. 195-206.

Haroooni, A. Q. A., Maddahy, M. H., Danaee, I. \& Nikmanesh, S., 2015. Corrosion Behavior of 6063 Alumunium Alloy in Ethylene GlycolWater Solution. Iranian Journal of Material Science \& Engineering, 12(4), pp. 34-44.

Kakuba, G., 2005. The Impressed Current Cathodic Protection System. Eindhoven: Technische Universiteit Eindhoven .

Loto, C. A. \& Popoola, A. P. I., 2011. Effect of Anode and Size Variation on The Cathodic Protection of Mild Steel in Sea Water and Sulphuric Acid. Volume 6.
Hashim, M., Mohammed, K. \& Hamadi, N. J., 2014. Modeling and Control of Impressed Current Cathodic Protection (ICCP) System. Iraq J. Electrical and Electronic Engineering.

Hogan, V. G. D. E., Lucas, K. E. \& Wimmer, S. A., 2005. Shipboard impressed current cathodic protection system (ICCP) analysis. WIT Transactions on State of the Art in Science and Engineering.

Ivanov, H., 2016. Corrosion Protection System in Offshore Structure. Ohio: University of Akron.

Janowski, M. \& Wantuch, A., 2016. ICCP cathodic protection of tanks with photovoltaic supply. SEED, p. 10.

Javadi, M., J.Javidan \& Salimi, M., 2014. Cathodic Protection of an underground Pipeline by Photovoltaic Power System using Intelligent Method. International Journal of Renewable Energy Research, pp. 267-274.

NACE, 2002. NACE Corrosion Engineer's Reference Book. Houston: NACE International The Corrosion Society.

Nguyen, C. V. et al., 2012. International Scholarly Research Network. the Performance of Carbon Fibre Composites as ICCP anodes for reinforced Concrete Structures, pp. 1-9. 